\title{
Antibacterial Activity of Propolis Ethanol Extract Against Streptococcus mutans as Influenced by Concentration, Temperature, $\mathrm{pH}$ and Cell Age
}

\author{
HSIN-YI YANG ${ }^{1,3}$, WEI-LI HO ${ }^{2}$, CHENG-MING CHANG ${ }^{3}$ AND CHENG-CHUN CHOU ${ }^{1 *}$ \\ 1. Graduate Institute of Food Science \& Technology, National Taiwan University, Taipei City 106, Taiwan, R.O.C. \\ 2. Department of Food Science and Technology, Ching Kuo Institute of Management and Health, Keelung, Taiwan, R.O.C. \\ 3. Department of Food Science, National Taiwan Ocean University, Keelung, Taiwan, R.O.C.
}

(Received: July 12, 2006; Accepted: November 10, 2006)

\begin{abstract}
In the present study, the ethanol extract of propolis (EEP) collected in Taiwan was prepared and assayed for the effects concentration, incubation temperature, $\mathrm{pH}$ and cell age on the antimicrobial activity against Streptococcus mutans, a dental cavitycausing oral pathogen. Additionally, cell leakage of Str. mutans in presence of EEP was also examined.

It was found EEP exerted bacteriostatic and bactericidal effects against Str. mutans, respectively, at concentrations of 1.875 and $3.75 \mu \mathrm{g} / \mathrm{mL}$ or more. At $37^{\circ} \mathrm{C}$, Str. mutans was more sensitive to EEP than at $25^{\circ} \mathrm{C}$ while most resistant at $4^{\circ} \mathrm{C}$. Cells of test organism were most susceptible to EEP at acid $\mathrm{pH}$ followed by neutral and alkaline $\mathrm{pH}$. It was also noted that cells of Str. mutans in the stationary phase were more resistant, while cells in the mid-exponential phase were more susceptible to EEP. After exposure to EEP, a marked increase in the $260 \mathrm{~nm}$ absorbance for the supernatant of culture, was observed, indicating the release of UV-absorbing materials. Scanning electron micrographs also showed an increase in material with irregular shape on the surface of EEP-treated Str. mutans cells.
\end{abstract}

Key words: antibacterial activity, cell leakage, ethanol extract of propolis, Streptococcus mutans

\section{INTRODUCTION}

Propolis, a resinous substance, is derived from the plant resins which was collected by honeybees. Bees use it as a glue, general-purpose sealer and draughtextruder for beehives ${ }^{(1)}$. Antimicrobial activity of propolis has been reported by various investigators ${ }^{(2-5)}$. Researchers have noted that the antimicrobial activity of propolis reflects its composition, which may vary with the area and season ${ }^{(3,5-8)}$. It has also been reported that propolis, despite exerting antimicrobial activity on gram $(+)$ bacteria, showed no activity on gram $(-)$ bacteria $^{(9-10)}$. In addition to antimicrobial activity, propolis has also been found to possess antioxidative and antiulcer activities. For these reasons, propolis is now considered as a useful ingredient for the applications in domestic goods, medicine, and food products.

Streptococcus mutans is the leading cause of dental cavities (tooth decay) worldwide and is considered to be the most cariogenic among the oral streptococci. It has been shown that there is a positive correlation between the number of Str. mutans in dental plaque and the occurance of dental cavities ${ }^{(11-12)}$. Str. mutans can colonize the tooth surface and initiate plaque formation through the synthesis of extracellular polysaccharides,

\footnotetext{
* Author for correspondence. Tel: +886-2-33664111;

Fax:+886-2-23620849; E-mail: fstcchou@ntu.edu.tw
}

mainly water-insoluble glucan from sucrose by using glucosyltransferase ${ }^{(13)}$. Park et al. ${ }^{(4)}$ reported that ethanol extract of propolis (EEP) from various regions in Brazil inhibited both glucosyltransferase activity and the growth of Str. mutans. In addition, Koo et al. ${ }^{(13)}$ observed that EEP exhibited in vitro antibacterial activity, the inhibition of cell adherence and the formation of water-insoluble glucan. Despite these findings, information concerning the factors that mediate the antimicrobial activity of propolis against Str. mutans is still lacking. Therefore, this study investigated the effects of concentration, incubation temperature, $\mathrm{pH}$ and cell age on the the susceptibility of Str. mutans to EEP. Besides, leakage of nucleic materials from cells of Str. mutans in presence of EEP was also examined.

\section{MATERIALS AND METHODS}

\section{Test Organism and Propolis}

Str. mutans BCRC 15256 was obtained from the Bioresource Collection and Research Center, Hsingchu, Taiwan. To activate the test organism before experimentation, Str. mutans was transferred twice successively in tryptic soy broth (TSB, Difco, Detroit, MI, USA) at $37^{\circ} \mathrm{C}$ for $24 \mathrm{hr}$. The inoculum was then prepared by inoculat- 
ing $0.1 \mathrm{~mL}$ of the activated culture into $10 \mathrm{~mL}$ of TSB and incubated at $37^{\circ} \mathrm{C}$ for $16 \mathrm{hr}$, except for the cell age experiments during which cells were cultured for 10, 16 and 30 $\mathrm{hr}$ to obtain the mid-exponential, late-exponential and stationary phase cells, respectively. These cultures were then properly diluted with sterile saline $(0.85 \% \mathrm{NaCl})$ and used as inoculum in the susceptibility test.

The propolis was collected from beehives located in Nantou County, Taiwan in June and July of 2003. They were stored at $-30^{\circ} \mathrm{C}$ before use. Twenty five grams of ground propolis was extracted by $250 \mathrm{~mL}$ of $80 \%$ ethanol by orbital shaking at $150 \mathrm{rpm}$ at $25^{\circ} \mathrm{C}$ for $48 \mathrm{hr}$. The ethanol extract was then filtered through a Whatman \#42 filter paper and restored to its original volume by adding $80 \%$ ethanol. Various concentrations of EEP solution were further made by diluting with the appropriate amounts of $80 \%$ ethanol based on the dry weight.

\section{Study on the Susceptibility of Str. mutans to EEP}

When the effect of EEP concentration was examined, $9.8 \mathrm{~mL}$ of TSB was mixed with $0.1 \mathrm{~mL}$ of the EEP solution of various concentrations EEP or $0.1 \mathrm{~mL}$ of $80 \%$ ethanol as control. They were then inoculated with 0.1 $\mathrm{mL}$ of the inoculum of Str. mutans BCRC 15256 to give an initial population of ca $10^{4}-10^{5} \mathrm{CFU} / \mathrm{mL}$. The viable population of Str. mutans was determined after $12 \mathrm{hr}$ of incubation at $37^{\circ} \mathrm{C}$.

To examine the effect of temperature, $98.0 \mathrm{~mL}$ of TSB was added to $1.0 \mathrm{~mL}$ of the EEP or $80 \%$ ethanol (control). This mixture was inoculated with $1.0 \mathrm{~mL}$ of the inoculum of Str. mutans to give an initial population of ca $10^{5} \mathrm{CFU} / \mathrm{mL}$ and incubated at 4,25 or $37^{\circ} \mathrm{C}$ for $12 \mathrm{hr}$. The viable population of the test organism in the samples taken at predetermined time intervals was determined.

To perform the experiment of $\mathrm{pH}$ effect, $98.0 \mathrm{~mL}$ of TSB of $\mathrm{pH} 5.0,6.0,7.1,8.0$ or 9.0 was added to EEP or $80 \%$ ethanol (control) and inoculated with Str. mutans and incubated at $37^{\circ} \mathrm{C}$ for $12 \mathrm{hr}$.

When the effect of cell age was examined, 98.0 $\mathrm{mL}$ of TSB was first mixed with $1.0 \mathrm{~mL}$ of EEP or $80 \%$ ethanol (control) and inoculated with $1.0 \mathrm{~mL}$ of the prepared inoculum containing mid-exponential, lateexponential or stationary phase cells of Str. mutans, which gave an initial population of ca $10^{5} \mathrm{CFU} / \mathrm{mL}$. They were then incubated at $37^{\circ} \mathrm{C}$ for $12 \mathrm{hr}$. The viable population in the samples taken after certain periods of incubation was also determined.

\section{Study on Cell Leakage}

Str. mutans BCRC 15256 cells in the late-exponential growth phase were recovered by centrifugation at $8,000 \times \mathrm{g}$ for $15 \mathrm{~min}$, washed with saline three times, and resuspended in saline solution with proper dilution. One milliliter of the cell suspension was combined with $98.0 \mathrm{~mL}$ of saline solution and $1.0 \mathrm{~mL}$ of $80 \%$ ethanol (control) or $1.0 \mathrm{~mL}$ of $80 \%$ ethanol containing EEP $(200.0 \mu \mathrm{g} / \mathrm{mL})$. They were then incubated at $37^{\circ}$ $\mathrm{C}$ for $12 \mathrm{hr}$. At various time intervals, samples were taken to determine the viability and were centrifuged at $8,000 \times \mathrm{g}$ for $15 \mathrm{~min}$. Leakage of nucleic acid materials in supernatant was measured by the absorbance at $260 \mathrm{~nm}$ using a spectrophotometer.

\section{Scanning Electron Microscopy (SEM)}

The method described by Fukushima et al. ${ }^{(14)}$ was emoloyed to prepare samples for electron microscopy. The cell pellets samples were fixed in $2.5 \%$ glutaraldehyde in $0.1 \mathrm{M}$ Tris buffer $\left(\mathrm{pH} \mathrm{7.3)}\right.$ at $4^{\circ} \mathrm{C}$ for $1 \mathrm{hr}$. After being washed twice in a Tris buffer with $5 \%$ sucrose, they were post-fixed in $1.0 \%$ osmium tetroxide solution in the same buffer for $1 \mathrm{hr}$. The resultant osmium-treated cells were then washed with $0.1 \mathrm{M}$ Tris buffer and dehydrated by successive extractions with $50,70,80,90$ and $95 \%$ ethanol, each for a period of $10 \mathrm{~min}$, and finally with $100 \%$ ethanol for 15 min twice. They were then dried by the $\mathrm{CO}_{2}$ critical-point drying technique, coated with gold and examined using a scanning electron microscope (Model JSM-6300, JEOL, Tokyo, Japan).

\section{Enumeration of Str. mutans}

To determine the viable population of Str. mutans, samples were first serially diluted with sterile saline. Viable counts were then made by pour-plating $(1.0 \mathrm{~mL})$ on tryptic soy agar (TSA, Difco, Detroit, MI, USA). The colonies were counted after 48-72 hr of incubation at $37^{\circ} \mathrm{C}$.

\section{Statistical Analysis}

In this study, each experiment was carried out in triplicate. The mean value and standard deviation were calculated from the data obtained. These results were then compared using the least significant difference (LSD) test ${ }^{(15)}$.

\section{RESULTS AND DISCUSSION}

\section{Effect of Concentration}

The survival of Str. mutans in presence of various amounts of EEP is shown in Figure 1. In contrast to that observed in Salmonella typhimurium and Escherichia coli, but in accordance with that noted in Staphylococcus aureus and Listeria monocytogenes ${ }^{(5,16)}$, propolis extract exhibited antibacterial activity against Str. mutans. The propolis extract, depending on the concentration tested, displayed bacteriostatic and bactericidal effects on Str. mutans in TSB. At a dosage of $3.75 \mu \mathrm{g} / \mathrm{mL}$ or more, propolis extract exerted a bactericidal effect on the test organism. No viable 


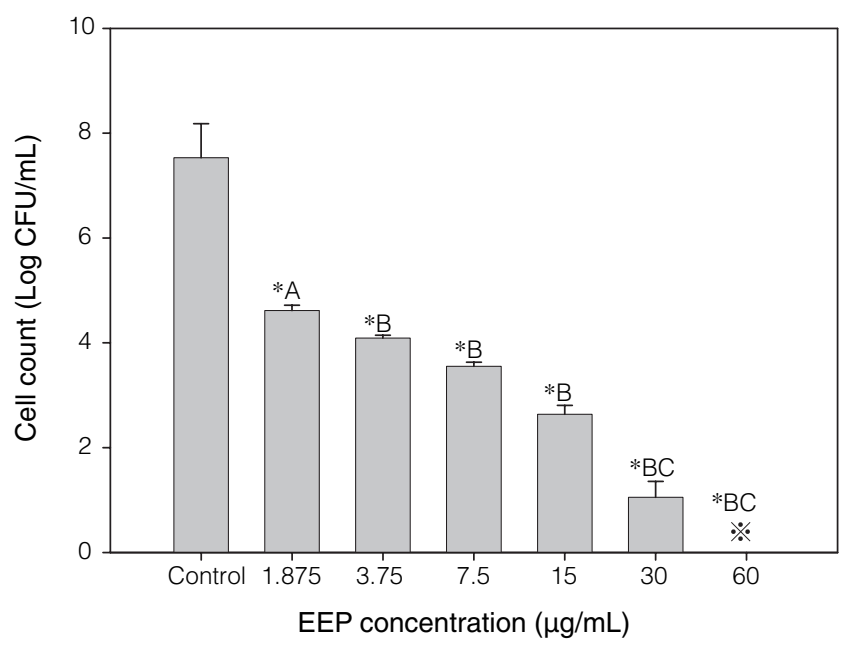

Figure 1. Survival of Str. mutans after $12 \mathrm{hr}$ of cultivation in TSB containing various amounts of EEP. Str. mutans was inoculated into TSB at an initial population of ca $10^{4}-10^{5} \mathrm{CFU} / \mathrm{mL}$. ※ indicates no viable cell detected. ${ }^{*}$ The final population was significantly lower $(p<0.05)$ than that of the control by LSD test. (A) The final population was not significantly different $(p>0.05)$ with initial population by LSD. (B) The final population was significantly lower $(p<0.05)$ than initial population by LSD. (C) Survival cell was less than $0.1 \%$ of the initial population.

cell was detected in TSB containing $60 \mu \mathrm{g} / \mathrm{mL}$ of EEP after $12 \mathrm{hr}$ of cultivation while propolis extract at a concentration of $1.875 \mu \mathrm{g} / \mathrm{mL}$ did not affect inhibite the growth of test organism. Testing in brain heart infusion broth with a similar level of initial population, a relatively high dosage of $3.75 \mu \mathrm{g} / \mathrm{mL}$ was required to exert the bacteriostatic effect on L. monocytogenes ${ }^{(17)}$. Therefore, Str. mutans seems to be more susceptible to EEP than L. monocytogenes.

Propolis collected in Taiwan contains flavones, flavonols, flavonones and isoflavones ${ }^{(18)}$. These constituents in propolis may contribute to the antimicrobial activity observed $^{(19)}$.

\section{Effect of Temperature}

The effect of propolis extract on the growth and survival of Str. mutans in TSB at different cultural temperatures is shown in Figure 2. Neither growth nor reduction in the viable population of Str. mutans was noted in TSB with or without EEP during $12 \mathrm{hr}$ of incubation period at $4^{\circ} \mathrm{C}$. However, when Str. mutans grew at 25 or $37^{\circ} \mathrm{C}$ in TSB, EEP showed bactericidal effect on Str. mutans during the incubation period. In general, the difference between the viable populations of test organism in the TSB with, and without EEP enhanced as the incubation period extended. This effect was more profound at $37^{\circ} \mathrm{C}$. For example, the test organism in TSB without EEP showed a viable population of ca 7.8 $\log \mathrm{CFU} / \mathrm{mL}$ which is higher than that in TSB containing propolis extract by $2.6 \log \mathrm{CFU} / \mathrm{mL}$ after $12 \mathrm{hr}$ of

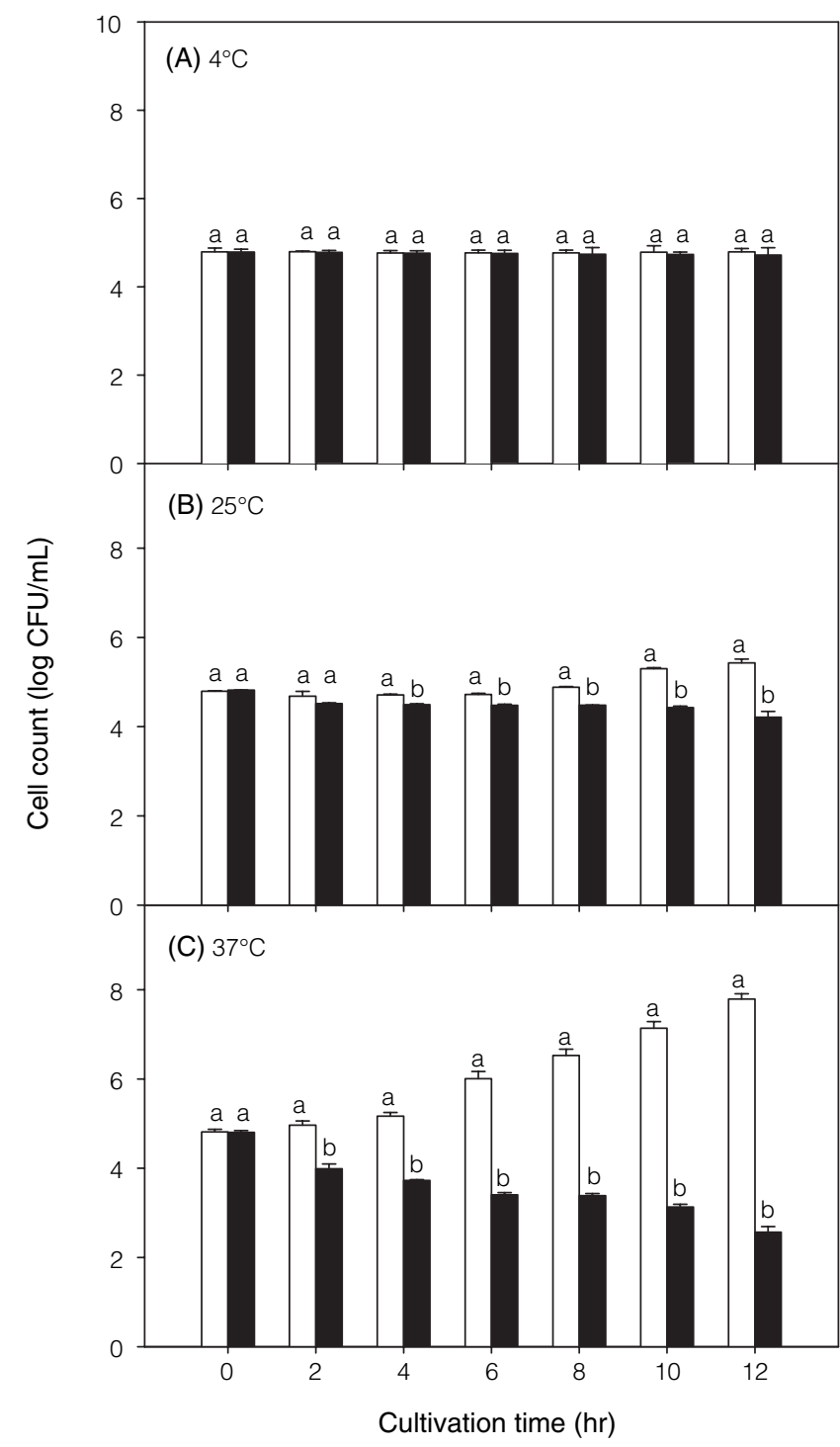

Figure 2. Susceptibility of Str. mutans to EEP at various cultivation temperatures. Viable cells of Str. mutans were determined after 12 hr of cultivation in TSB containing $15 \mu \mathrm{g} / \mathrm{mL}$ EEP (๘) or without EEP ( $\square$ ). Each bars for the control or for the treated sample bearing different lowercase letters are significantly different by Duncan's multiple range test $(p<0.05)$.

incubation at $37^{\circ} \mathrm{C}$. Meanwhile, the difference between the viable populations of the control and EEP-containing TSB was only $1.2 \log \mathrm{CFU} / \mathrm{mL}$ when the test organism was incubated at $25^{\circ} \mathrm{C}$. This finding is consistent with that observed on Sta. aureus and it is further suggested that Str. mutans is more susceptible to propolis extract at higher temperatures. The metabolic rate of Str. mutans is higher at $37^{\circ} \mathrm{C}$ than at other temperatures examined. Cells with higher metabolic rates are more susceptible to antimicrobials. Moreover, the reaction rate between the antimicrobial principles and microbial cells increased as the temperature was elevated ${ }^{(20)}$. These effects may all contribute to the phenomenon observed. 


\section{Effect of $p H$}

$\mathrm{pH}$ level is one of the most important factors concerning the activity of antimicrobial compounds ${ }^{(21)}$. The susceptibility of Str. mutans to the propolis extract at various pH levels is shown in Figure 3. At $\mathrm{pH}$ 6.0-9.0,

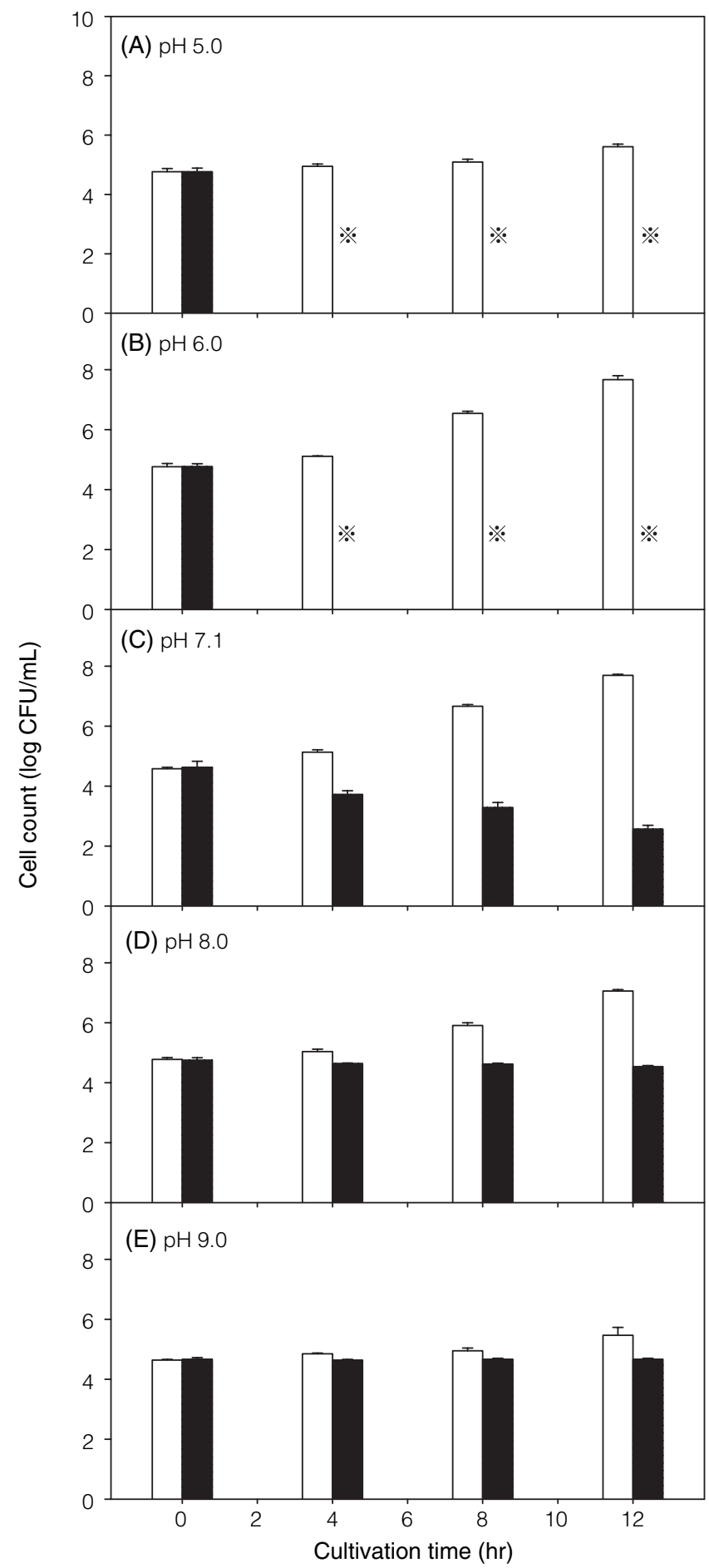

Figure 3. Susceptibility of Str. mutans to EEP at various cultivation pHs. Viable cells of Str. mutans were determined after $12 \mathrm{hr}$ of cultivation in TSB containing $15 \mu \mathrm{g} / \mathrm{mL}$ EEP (๘) or without EEP ( $\square$ ). ※ indicates no viable cell detected.
Str. mutans showed various levels of growth in TSB without the propolis extract. On the other hand, the viable population of test organism decreased in TSB containing propolis extract, regardless of $\mathrm{pH}$. Difference between the viable populations in control and EEP-containing medium varied with $\mathrm{pH}$ during the incubation period. After $4 \mathrm{hr}$ of incubation, no viable cell of Str. mutans was detected in the medium with a $\mathrm{pH}$ of 5.0 or 6.0. It was also noted that, in EEP-containing TSB with a higher $\mathrm{pH}$, a higher final viable population of Str. mutans was observed at the end of incubation. These results, similar to that observed on Sta. aureus ${ }^{(16)}$, demonstrated that the antimicrobial activity exerted by the propolis extract against Str. mutans increased as the $\mathrm{pH}$ of the medium decreased.

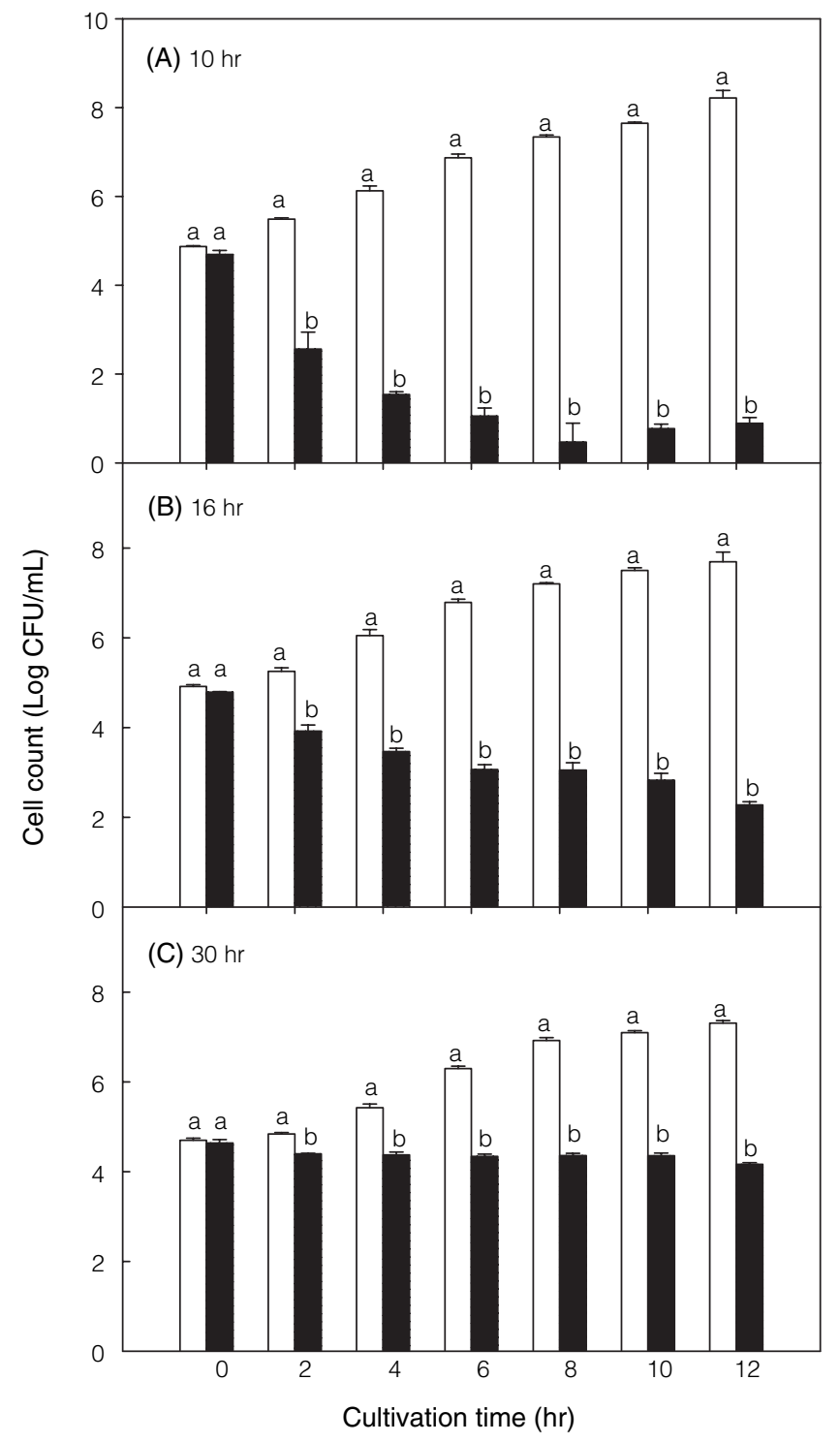

Figure 4. Effect of cell age on the susceptibility of Str. mutans to EEP. Viable cells of Str. mutans were determined after $12 \mathrm{hr}$ of cultivation in TSB containing $15 \mu \mathrm{g} / \mathrm{mL}$ EEP (๘) or without EEP ( $\square$ ). Each bars for the control or for the treated sample bearing different lowercase letters are significantly different by Duncan's multiple range test $(p<0.05)$. 
Bankova et al. ${ }^{(22)}$ indicated that polyphenol compounds belong to the main components contributing to the biological activity of propolis. Zhu et $a l .{ }^{(23)}$ demonstrated that some of the polyphenols were extremely unstable in alkali condition, but relatively stable in acid condition. Therefore, it is suggested that the degradation of these phenolic compounds in alkaline condition, especially at $\mathrm{pH} 9.0$, may thus diminish the antimicrobial activity of the propolis extract as observed at alkaline $\mathrm{pH}$.

\section{Effect of Cell Age}

Generally, microorganism, in log phase, the actively growing stage, are less resistant than those in the stationary phase ${ }^{(21)}$. Further, it has been suggested that the susceptibility of microorganisms at different cell ages to antimicrobials might vary with microorganism, test medium, and antimicrobials being examined ${ }^{(24-25)}$.

The effect of cell age on the susceptibility of Str. mutans to propolis extract is shown in Figure 4. Regardless of cell age, viable population of test organism in TSB containing no propolis extract increased as the incubation time extended and reached to ca 7.3-8.2 log $\mathrm{CFU} / \mathrm{mL}$ after 12 -hr incubation. The viable population of Str. mutans in stationary phase did not change markedly, while that of test organisms in the mid-exponential and late-exponential phases decreased in the propolis extract-containing TSB during the incubation period (Figure 4A and B). Cells of Str. mutans in mid-exponential phase were the most susceptible to propolis extract. Relative to the viable population observed in the control TSB, cells in the mid-exponential phase showed the highest population reduction of $7.3 \log \mathrm{CFU} / \mathrm{mL}$ as compared to that of $4.2 \log \mathrm{CFU} / \mathrm{mL}$ with the cells in the late-exponential phase at the end of incubation period. These observations, in accordance with those observed on L. monocytogenes ${ }^{(26)}$ shows that Str. mutans cells in the mid-exponential phase were most susceptible to propolis extract, followed by cells in the late-exponential and stationary phase.

\section{Effect of EEP on the Viability and Cell Leakage of Str. mutans in Saline Solution}

Similar to that observed in saline solution without EEP, the viability of test organism decreased, while the absorbance at $260 \mathrm{~nm}$ increased markedly, in the EEP-containing saline during the period of exposure (Figure 5).

Takaisi-Kikuni ${ }^{(27)}$ reported that propolis inhibited the growth of Str. agalactiae by preventing cell division. They also indicated that propolis disorganized the cytoplasm, the cytoplasmic membrane and the cell walls. As shown in Figure 6, the scanning electron micrographs showed the appearance of materials with irregular shapes around the cell surface of Str. mutans after exposure to saline with or without EEP. These

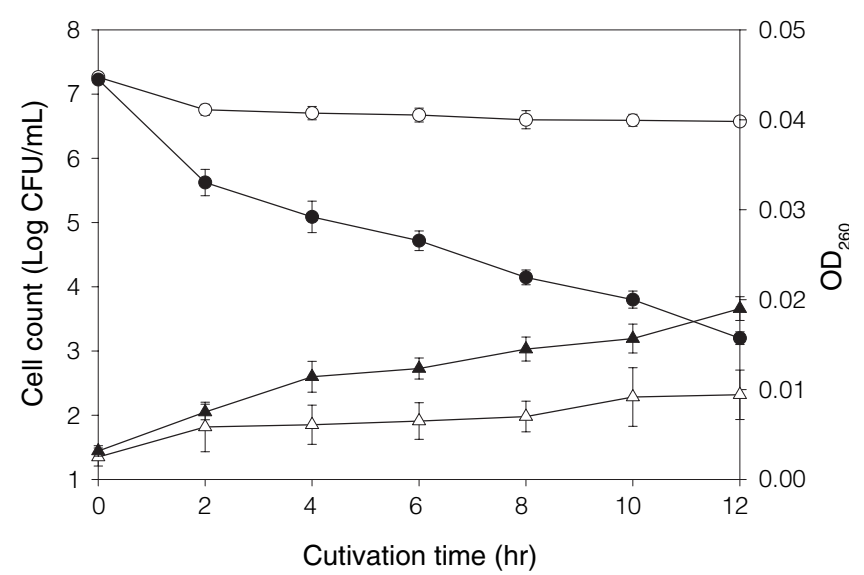

Figure 5. Effects of EEP on the viable cells and the leakage of 260-nm-absorbing materials from Str. mutans. The harvested Str. mutans cells $\left(10^{7} \mathrm{CFU} / \mathrm{mL}\right)$ were cultured with $0.85 \%$ sodium chloride solution containing $1.0 \mu \mathrm{g} / \mathrm{mL}$ EEP (solid symbols) or without EEP as control (open symbols). Cultures were incubated at $37^{\circ} \mathrm{C}$. Viable cells, $\bullet$ and $\circ ; \mathrm{OD}_{260}, \boldsymbol{\Delta}$ and $\triangle$.

materials increased as the exposure time extended and were more pronounced in the EEP-treated cells (Figure $6 \mathrm{D}$ and $\mathrm{E}$ ) than the control cells (Figure $6 \mathrm{~A}, \mathrm{~B}$ and $\mathrm{C}$ ). This observation along with the marked increase of 260 $\mathrm{nm}$ absorbance (Figure 5) demonstrates that EEP caused the injury on the cell membrane of Str. mutans and resulted in cell leakage.

\section{CONCLUSIONS}

Based on the results obtained from the present study, propolis gathered in Taiwan possesses antimicrobial activity against Str. mutans. EEP caused the leakage of nucleic acid materials from cells of Str. mutans. Str. mutans in their mid-exponential phase, at $37^{\circ} \mathrm{C}$ and $\mathrm{pH} 5.0$, were most susceptible to the EEP tested. These results indicated the possibility of using EEP as an active anti-Str. mutans ingredient in the dental cavities control medicines. Finally, factors mediating the susceptibility of Str. mutans to EPP as observed in this study should be further explored so that the most effective antimicrobial action of EPP can be employed in practical applications.

\section{REFERENCES}

1. Crane, E. 1997. The past and present importance of bee products to man. In "Bee Products: Properties, Applications, and Apitherapy". pp. 1-14. Plenum Press. New York, U. S. A.

2. Grange, J. M. and Davey, R. W. 1990. Antibacterial properties of propolis (bee glue). J. R. Soc. Med. 83: 159-160. 

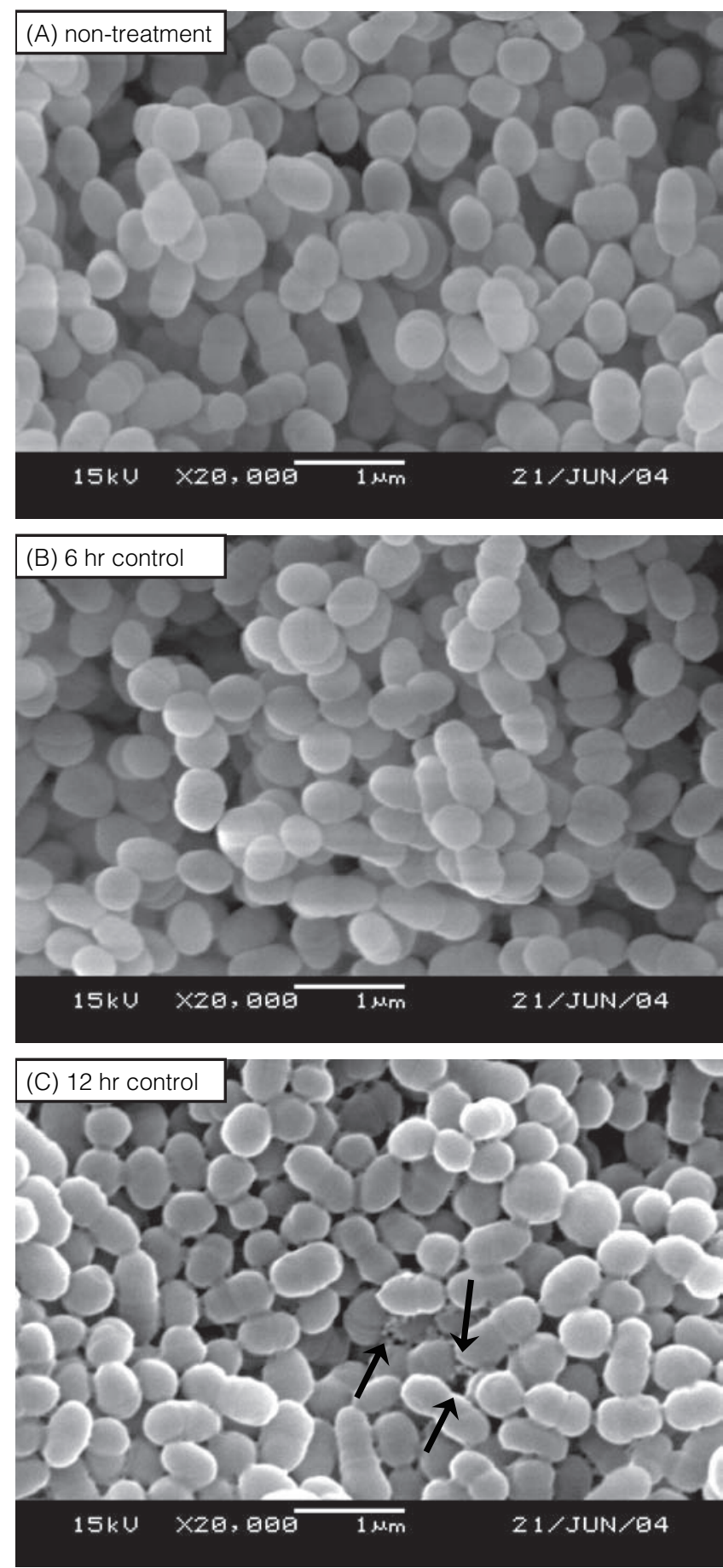

3. Sforcin, J. M., Fernandes, A., Lopes, C. A. M., Bankova, V. and Funari, S. R. C. 2000. Seasonal effect on Brazilian propolis antibacterial activity. J. Ethnopharmacol. 73: 243-249.

4. Park, Y. K., Koo, M. H., Abreu, J. A. S., Ikegaki, M., Cury, J. A. and Rosalen, P. L. 1998. Antimicrobial activity of propolis on oral microorganisms. Curr. Microbiol. 36: 24-28.

5. Lu, L. C., Chen, Y. W. and Chou, C. C. 2003. Antibacterial and DPPH free radical-scavenging activities of the ethanol extract of propolis collected in
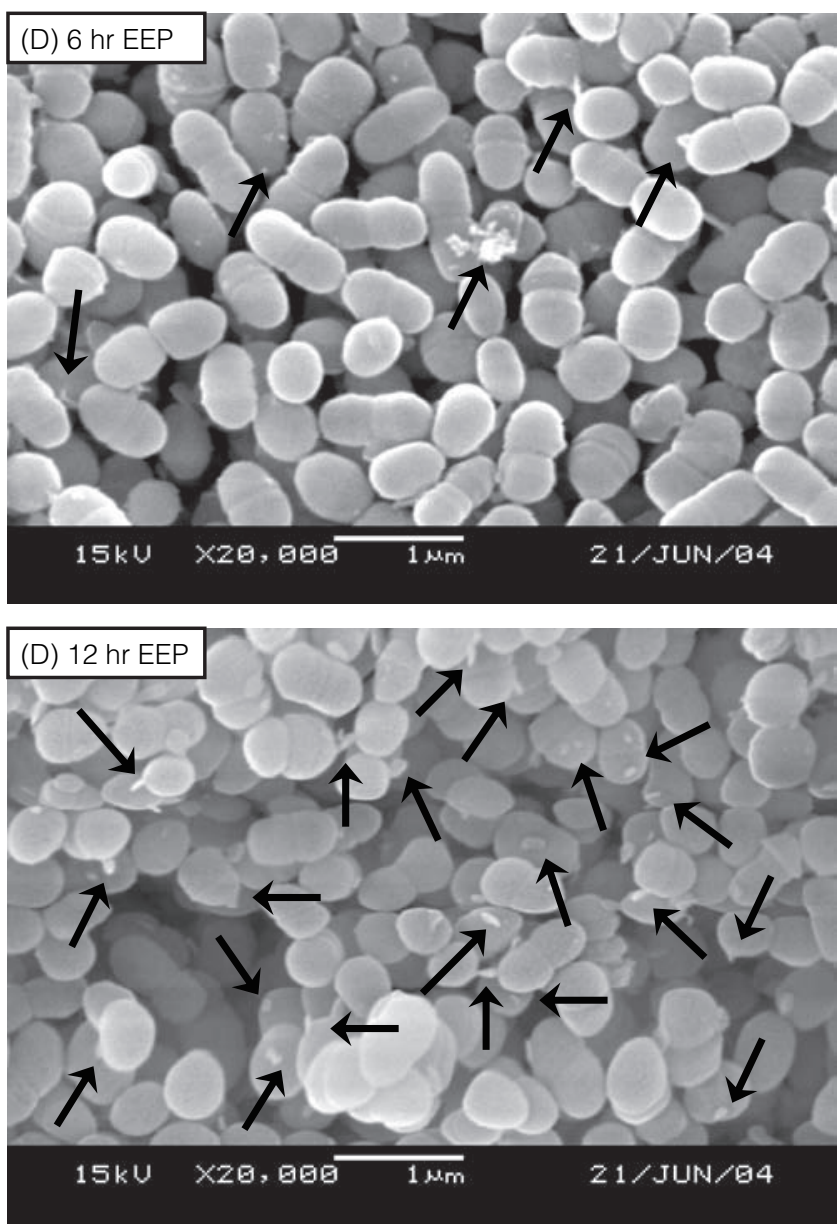

Figure 6. Scanning electron micrographs of Str. mutans cells. (A) cells before exposure to saline solution. (B) and (C) cells exposure to saline solution containing ethanol without EEP (control) for 6 and $12 \mathrm{hr}$, respectively. (D) and (E) cells exposure to saline solution containing EEP for 6 and $12 \mathrm{hr}$, respectively. Arrows show cell leakage materials. Magnification: $\times 10,000$.

Taiwan. J. Food Drug Anal. 11: 277-282.

6. Serra, J. and Escola, R. 1995. A study of the bacteriostatic activity of propolis. Deutsche Lebensmittelrundschau 91: 242-246.

7. Hegazi, A. G., Hazzaa, M. and Abd El-Aziz, A. 1996. Antifungal activity of Egyptian propolis. J. Union Arab. Biol. 3: 67-75.

8. Hegazi, A. G., Abd El-Hady, F. K. and Abd Allah, F. A. M. 2000. Chemical composition and antimicrobial activity of European propolis. J. Biosci. 55: 70-75.

9. Kujumgiev, A., Tsvetkova, I., Serkedjieva, Y., Bankova, 
V., Christov, R. and Popov, S. 1999. Antibacterial, antifungal and antiviral activity of propolis of different geographic origin. J. Ethnopharmacol. 64: 235-240.

10. Moreno, M. I. N., Isla, M. I., Cudmani, N. G., Vattuone, M. A. and Sampietro, A. R. 1999. Screening of antibacterial activity of Amaicha del Valle (Tucuman, Argentina) propolis. J. Ethnopharmacol. 68: 97-102.

11. De Stoppelaar, J. D., Van Houte, J. and Backer Dirks, O. 1969. The relationship between extracellular polysaccharide-producing streptococci and smooth surface caries in 13-year-old children. Caries Res. 3: 190-199.

12. Ikeda, T., Sandham, H. J. and Bradley, E. L. 1973. Changes in Streptococcus mutans and lactobacilli in plaque in relation to the initiation of dental caries in Negro children. Arch. Oral Biol. 18: 555-566.

13. Koo, H., Rosalen, P. L., Cury, J. A., Ambrosano, G. M. B., Murata, R. M., Yatsuda, R., Ikegaki, M., Alencar, S. M. and Park, Y. K. 2000. Effect of a new variety of Apis mellifera propolis on mutans streptococci. Curr. Microbiol. 41: 192-196.

14. Fukushima, Y., Okamura, K., Imai, K. and Motai, H. 1988. A new immobilization technique of whole cells and enzymes with colloidal silica and alginate. Biotechnol. Bioeng. 32: 583-594.

15. SAS. 2001. SAS User's Guide: Statistics SAS Institute. Version 8. Gary, N. C. ed.

16. Lu, L. C., Chen, Y. W. and Chou, C. C. 2005. Antibacterial activity of propolis against Staphylococcus aureus. Int. J. Food Microbiol. 102: 213-220.

17. Yang, H. Y., Chang, C. M., Chen, Y. W. and Chou, C. C. 2006. Inhibitory effect of propolis extract on the growth of Listeria monocytogenes and the mutagenicity of 4nitroquinoline-N-oxide. J. Sci. Food Agric. 86: 937-943.
18. Chang, C. C., Yang, M. H., Wen, H. M. and Chern, J. C. 2002. Estimation of total flavonoid content in propolis by two complementary colorimetric methods. 10: 178182.

19. Hema'ndez, N. M. R. and Bemal, K. C. 1990. Efecto antibio'tico del propo'leo frente a cepas de Staphylococcus aureus origen clinico humano. Rev. Cubana Farm. 24: 45-50.

20. Banwart, G. J. 1999. Basic Food Microbiology. 3rd ed. Van Nostrand Reinhold. New York, U. S. A.

21. Jay, J. M. 2000. Modern food microbiology. 6th ed. Aspen Publishers Inc. Bakar Batu, Singapore.

22. Bankova, V., Dyulgerov, A., Popov, S. S. and Marekov, N. L. 1983. A study on flavonoids of propolis. J. Nat. Prod. 46: 471-474.

23. Zhu, Q. Y., Zhang, A., Tsang, D., Huang, Y. and Chen Z. Y. 1997. Stability of green tea catechins. J. Agric. Food Chem. 45: 4624-4628.

24. Tsai, G. J. and Su, W. H. 1999. Antibacterial activity of shrimp chitosan against Escherichia coli. J. Food Prot. 62: 239-243.

25. Chen, Y. L. and Chou, C. C. 2005. Factors affecting the susceptibility of Staphylococcus aureus CCRC 12657 to water soluble lactose chitosan derivative. Food Microbiol. 22: 29-35.

26. Yang, T. C., Chou, C. C. and Li, C. F. 2004. Antibacterial activity of $\mathrm{N}$-alkylated disaccharide chitosan derivatives. Int. J. Food Microbiol. 97: 237245.

27. Takaisi-Kikuni, N. B. and Schilcher, H. 1994. Electron microscopic and microcalorimetric investigations of the possible mechanism of the antibacterial action of a defined propolis provenance. Planta Med. 60: 222-227. 